\title{
Accounting Disclosure Practices - An Over View
}

\author{
Komati Durga Prasad ${ }^{1}$, Soofi Asra Mubeen ${ }^{2}$, Banda Rajani ${ }^{3}$ \\ ${ }^{1}$ ICFAI Law School, Management Faculty, ICFAI Foundation for Higher Education, Hyderabad, India \\ ${ }^{2}$ Business Studies Department, Higher College of Technology, Muscat, Oman \\ ${ }^{3}$ Department of Commerce and Business Management, Chaitanya Deemed to Be University, Warangal, India
}

Email address:

komatiprasad@gmail.com (K. D. Prasad), soofi.asra@gmail.com (S. A. Mubeen), komatirajani@gmail.com (B. Rajani)

\section{To cite this article:}

Komati Durga Prasad, Soofi Asra Mubeen, Banda Rajani. Accounting Disclosure Practices - An Over View. Journal of Finance and Accounting. Vol. 8, No. 4, 2020, pp. 208-211. doi: 10.11648/j.jfa.20200804.16

Received: March 4, 2020; Accepted: June 8, 2020; Published: August 19, 2020

\begin{abstract}
The accounting principles consist of both concepts and conventions. Among different conventions, the disclosure convention is the most important one. The information should be presented in such a manner that it can be easily understood by a person of average knowledge and prudence. The Company Act 1956 not only requires that Income Statement and Balance Sheet of a company must give prescribed forms in which these statements are to be prepared. In recent years, many business enterprises have broadened the scope of their activities to different industries foreign counties and market. Due to the growth of diversified business and expansion of firms into foreign market, consolidated information becomes non-homogeneous information. The problems of disclosure can be resolved in the light of the objectives of financing reporting. The methods of disclosure include Income Statement, balance Sheet, Statement of Retained earnings, and Funds Flow statement.
\end{abstract}

Keywords: Accounting, Conventions, Accounting Standards, Generally Accepted Accounting Principles

\section{Introduction}

Accounting is a language of business, through which normally a business house communicates with the outside world. In order to create this language intelligible and normally understood by all, its necessary thatought to be supported sure uniform scientifically ordered down standards. [4]

These standards are termed as accounting principles. The accounting principles consist of both concepts and conventions [1]. Among different conventions, the disclosure convention is the most important one. According to this convention, accounting reports ought to disclose absolutely and fairly the data they purport to represent. They should be honestly ready and may sufficiently disclose info that is of fabric interest to proprietors, gift and potential creditors and investors. [3]

The Company Act 1956 not only requires that Income Statement and Balance Sheet of a company must give prescribed forms in which these statements are to be prepared. The practice of appending notes to the accounting statements is in pursuant to the convention of full disclosure.
Meaning and Significance of Full Disclosure:

Disclosure implies publication of all economic information related to the accounting entity. The information to be disclosed to be of significance for informs decision making to the user of the financial information. This would increase the relevance and reliability of accounting information [19].

Full disclosure is important for the following reasons:

1. Under GAAP (Generally Accepted Accounting Principles) alternative accounting procedures, such as depreciation methods, inventory methods and the methods of revenue recognition, are used under different circumstances. [22]

2. Company normally makes changes in accounting or reporting procedures which affect the comparability of financial statements. For example a company may change form, FIFO to LIFO in accounting for inventory valuation.

3. Accounting disclosure help the smooth functioning of capital market by providing additional information contained the basic financial statements, which would help us in making proper investment decisions. 


\section{Objectives of the Study}

1. To present the need and importance of disclosure.

2. To explain the different methods of disclosure of accounting information.

3. To identify the problems in the disclosure practices.

4. To describe the disclosure practices in India.

5. To provide suggestions for effective disclosure practices.

Methods of Disclosure:

The information should be presented in such a manner that it can be easily understood by a person of average knowledge and prudence [2]. He should derive the same meaning from the information as it is prepared to covey. The methods of disclosure of information have evolved as a result of the changing environment and consequential improvement in the ways presentation effected by accountants on their own, on the recommendations of professional institutes and as result of government measures. Still, there are no hard and fast methods of the presentation. They differ from country to country, even from a company to company in the same country.

Accounting Standard - I Disclosure:

Accounting Standard-I disclosure of significant accounting policies followed in the preparation and presentation of financial statements [6]. The areas in which accounting policies need disclosure include, methods of depreciation, depletion, amortization, treatment of expenditure during construction, conversion or translation of foreign currency items, valuation of inventories, treatment of good will, valuation of investment, treatment of retirements benefits, reconstitution of profit on long term on contracts, calculation of fixed assets and treatment of contingent liabilities [3].

This standard facilitates understanding of financial statements by disclosure of significant accounting polices contained in financial statements.

Additional Information:

Additional information can be disclosed in many ways: by way of parentheses, footnotes supplementary stalemates and schedules letters to shareholders, director report, auditor report, chairman speech.

There are various information sources available like Journal and magazines, reports analysis, economic statistics and new articles about companies.

Segment Reporting:

In recent years, many business enterprises have broadened the scope of their activities to different industries foreign counties and market [9]. Due to the growth of diversified business and expansion of firms into foreign market, consolidated information becomes non-homogeneous information. Consolidated statements enable the management hidden information from external reporting. Some segments may be running at losses but the consolidated stamens will merely show the averages profit figure of all the segments taken together [12]. Therefore, it is necessary to provide to the information users consolidated and segment information.

Disclosure in Interim Financial Reports
The following information must be disclosed in interim Financial Reports.

1. Sales or gross revenues, provision for income taxes, extraordinary items, cumulative effect of change in accounting principle and practices and net income.

2. Primary earnings and fully diluted earnings per share during financial year.

3. Seasonal revenue costs and expenses.

4. Significant changes in estimates provision for income taxes

5. Disposal of a segment of business and extraordinary, unusual, infrequently occurring items.

6. Contingent items

7. Changes in accounting principles or estimates

8. Significant changes in financial position.

The foregoing information with respect to current quarter and the current year-to-year or the last 12 months -to-date shall be furnished together with comparable data for the preceding year. The interim reports should disclose any change in accounting principles or accounting estimates. [25]

Disclosure in Interim Reporting in India:

The union Government of India has amended clause 41 of the listing agreement between companies and stock exchanges to ensure adequate disclosure by the listed companies about their financial performance to the investing public. [26]

All the listed companies will have to disclose:

1. Unaided financial results on half-yearly basis in pre-set form within two months of the expiry of the period to stock exchange where the company is listed.

2. Advertise the details within 48 hours of the disclosure in at least once English national daily.

The present Performa required the company give:

1. Financial details for six months ended, the corresponding six months in the previous year and the details of the previous accounting year.

2. The accounts as above will have to be signed by the Managing Director.

3. The company will have to hold a Board Meeting and advertise its date at least 15 days in advance.

4. The Half-yearly accounts shall be prepared on the basis of the accrual accounting policy.

5. Any information relating to material changes in the company performance must be disclosed separately.

6. Information like completion of expansion or diversification plans, labour troubles, changes in management, conversion of debentures into shares or may other material development, if it has incurred within six months.

If the sum total of the first half-year and the second half year unaudited results in respect of any item in the Performa varies by 20 percent when compared with the audited results for the full year, the company will have to explain reasons to the stock exchanges. However if the company intimates to the stock exchanges that it will publish audited results within three months of the closure of the accounting year, then the unaudited results for the second half-year need not be 
published or given to the SEBI. [23]

The Problems of Disclosure:

The problems of disclosure can be resolved in the light of the objectives of financing reporting. All countries do not have the same objectives. Basically the following questions relating to disclosure need to be answered.

1. Who are the users of information i.e., whom is the information to be disclosed?

2. How much information should be disclosed?

3. What should be disclosed?

4. How should it be disclosed?

Who are the users of Information?

The users of accounting information include owners, investors and creditors who are common to all countries in the world. But employees, customer's society, government and many others are also regarded as users [15].

How much Information should is disclosed?

All possible information relating to an entity cannot be disclosed in financing statements, that would make financial statements widely large, costly and perhaps more confusing equality, relevant information must not be concealed from investors, creditors, and others. The information which is material (i.e., which is capable of affecting judgment) to external decision makers must be disclosed. A balance sheet between the two extremes has to strike while deciding about disclosure of financial information. [14]

Hendriksen says that the "three basic concepts of disclosure generally proposed are adequate, fair and full disclosure. "Adequate disclosure means a minimum amount of disclosure so that the financial statements are not misleading. For unbiased and impartial information fair disclosure is essential. [18]

The ethical objective requires that here is equal treatment for all potential readers. Full disclosure implies presentation of relevant necessary information. Hence, the answer to this question is that the users of financial statements should be provided with all the significant and relevant information, keeping in view the objectives of financial reporting, which is immaterial, irrelevant or insignificant should be omitted "to make the presentation meaningful and understandable".

In actual proactive, however, it has been noticed that companies are generally reluctant to disclosure more information than what they are required to do under the law of the land or under professional pressure.

What should be disclosed?

Basic objectives of financial accounting will determine the required disclosure of information. This is also related to the class of users. All that information, which meets the needs of users in serving all the objectives, should be disclosed. The following information should be disclosed. [10]

1. The traditional financial statements namely, balance sheet, income statement, the statement of retained earnings, statement of changes in financial position, chairman, speech, directors report, auditor report that are usually included in the published annual reports of all the listed companies. This gives information on how the company has done in the past year, what its financial position was and what the sources and users of funds were. This is regarded as the minimum information required to be supplied to external users.

2. Besides the above, the laws of the land and professional pronouncements also require the following information to be disclosed in many countries.

i. Disclosure of accounting policies, including those valuations of assets.

ii. Any changes in Accounting Policies on methods of valuation, methods of changing depreciation, determination of earnings etc,.

iii. Events occurring after the balance sheet date.

iv. If certain Assets are pledged as security to specific creditors contingency liabilities and unreleased gains.

v. Disclosure of segment-wise accounting information (product wise and geographic division-wise)

vi. Interim reports of the company performance and finance position.

vii. Supplementary information on accounting adjustments changes in prices.

viii. Accounting for foreign transaction.

ix. Future prospects of the company.

\section{Conclusion and Suggestion}

Accounting must prepared and presented in such a manner that all material information must be disclosed in it. Full disclosure means disclosure of relevant information of significance to owners, investors and creditors. The company law has made several provisions for the disclosure of essential information in company accounts. The methods of disclosure include Income Statement, balance Sheet, Statement of Retained earnings, and Funds Flow statement. However, the disclosure convention involves money problems such as what information, how much information, to which it should be provided etc.

\section{References}

[1] Akhtarudding M (2005) Corporate Mandatory disclosure practices in Bangladesh, International Journal of Accounting.

[2] Abud Nasar, M and Tutherford B. A (1996), External users of financial reports in less developed countries. The case of Jordan, British Accounting Review 28 (1) pp 73-87. Http://du.doingorg/10.1066/bore.1996.

[3] Abdel Khalik. A. R., \& McKeown, J (1978), Understanding accounting changes in an efficient market: Evidence of differential reaction. The Accounting Review, 53 (43), 851868 .

[4] Anderson, r., Mansi, S., \& Reeb, D (2004). Board Characteristics, accounting report integrity, and the cost of debt. Journal of Accounting and Economics, 37 (3), 315-342.

[5] Altanuro J., \& Zhang H. (2013). The Financial Reporting of fair value based on managerial inputs versus market inputs: Evidence from mortgage servicing rights: Review of Accounting. 
[6] Bhusan R (1989), Firm Characteristics and Analyst. "Journal Accounting and Economics 11, 2/3, http://doi.org/10.1016/01654101(89)90008-6.

[7] Bradshaw, M. T., \& Sloan, R. G (2002). GAAP versus the street: An Empirical assessment of two alternative definitions of earnings. Journal of Accounting Research, 40 (1), 41-66.

[8] Botan C. A (1997), disclosure level and the cost of equity capital. "Accounting Review 72.

[9] Barth M (1994). Fair value accounting for banks Investments securities: What do bank share price tell us? Bank Accounting and Finance 7, 13-23.

[10] Cata sus (2008), In search of Accounting absence, Critical Perspective an Accounting 19 (7) 323-350.

[11] Carol A. Frost and Grace (1994), Accounting disclosure Practices in the United States and the U.K. Journal of Accounting Research. Vol. 32. No. 1, USA.

[12] Chirstenen H \& Nikolov V (2013) does fair value accounting for non-financial assets pass the market test? Review of accounting studies 18 (3) 734-775.

[13] Catasus B (2008). In search of Accounting absence, Critical Perspective on Accounting 19 (7) pp 1004-1009. http://dx.doi. Org/10.1111/0045-360900102.

[14] Fields, T., Lys, T., \& Vincent, L. (2001), Empirical research on accounting choice, Journal of Accounting and Economics, 31 (1-3), 255-307.

[15] Graham. J. R Harvey. C. r and Rajgopal (2005). The economic implications of corporate financial reporting, Journal of Accounting and Economics 40 pp 3037. http:/dx.doi.org/10.1016/j. Jacceo. 2005.

[16] International Accounting Standard Board (IASB) (2010), conceptual framework for financial reporting, 2010. London. UK. IASB.
[17] Lennox. C., Francis, J., \& Wang, Z. (2012). Selection models in accounting research. The Accounting Review, 87 (2). 589616.

[18] Jacvob. G Bimborg (1980). The Role of Accountings in financial Disclosure accounting, organization and society. Vol. Issue. 1.

[19] Lang -M Lundholm RC (1993), Cross -Sectional determinates of analyst ratings of corporate disclosure, Journal of Accosting Research 31 (2) pp 246-271, Http://dx.doi.org/10.2307/2491273.

[20] Sinner D (1997) Earning disclosures and stockholders lawsuit: Journal of Accounting and Economic 8 (1) pp 53-72. Http://dx.doi org/10.1016/165-4101 (01). 025-8.

[21] Song, C., Thomas, W., \& Yi, H. (2010). Value relevance of FAS 157 fair value hierarchy information and the impact of corporate governance mechanisms. The Accounting Review, 85 (4), 1375-1410.

[22] Nissim, D., \& Penman, S (2008). Principles for the application of fair value accounting, working paper, Columbia Business School Center for Excellence in Accounting and Security Analysis.

[23] Penman, S. (2007). Financial reporting quality: Is fair value a plus or a minus? Accounting and Busienss Research, Special Issue, 33-44.

[24] Yu; K (2013). Does recognition versus disclosure affect value relevance? Evidence from pension accounting. Accounting Review, 88 (3), 1095-1127.

[25] Watson A Srinivas P., Marton (2002) voluntary disclosure of accounting ratios in the U.K, British Accounting Review 34 (4). http://dx,org/10.1006/.2002 0213. 